\title{
GENETIC VARIATION AND DIFFERENTIATION IN MEXICAN POPULATIONS OF COMMON BUSH-TANAGERS AND CHESTNUT-CAPPED BRUSH-FINCHES ${ }^{1}$
}

\author{
A. Townsend Peterson \\ Division of Birds, Field Museum of Natural History, Roosevelt Road at Lake Shore Drive, \\ Chicago, IL 60605-2496
}

Patricia Escalante P.

Department of Ornithology, American Museum of Natural History, Central Park West at 79th Street, New York, NY 10024

\author{
Adolfo Navarro S. \\ Museo de Zoologia, Facultad de Ciencias, Universidad Nacional Autónoma de México, \\ Apartado Postal 70-399, México, DF 04510, México
}

\begin{abstract}
Genetic differentiation among four Mexican populations each of Common Bush-tanagers (Chlorospingus ophthalmicus) and Chestnut-capped Brush-finches (Atlapetes brunneinucha) was evaluated using allozyme electrophoresis. In both species, although levels of within-population variation are moderate, among-population variation is extreme, including fixed differences among populations. Genetic variation is significantly reduced in some populations on the smallest habitat islands. Differentiation is apparently unrelated to geographic distance among populations, and effects of habitat island size and isolation on genetic differentiation are not clear. Populations of the Sierra de los Tuxtlas in Veracruz, however, are strongly differentiated in both species.
\end{abstract}

Key words: Electrophoresis; genetic variation; genetic differentiation; cloud forest; tanager; brush-finch.

Resumen. La diferenciación genética entre cuatro poblaciones mexicanas del Saltón Chayotero (Atlapetes brunneinucha) y del Cerquero Verde (Chlorospingus ophthalmicus) fue estudiada usando electroforésis de alozimas. Los niveles de variabilidad intrapoblacional fueron moderados, pero la variabilidad entre poblaciones fue extrema, incluyendo diferencias fijas entre poblaciones, en ambas especies. La variación genética fue reducida significativamente en algunas poblaciones de las islas-habitat más pequeñas. Aparentemente, la diferenciación no está relacionada a la distancia geográfica entre poblaciones, y los efectos de tamaño de la isla-habitat y de aislamiento sobre la diferenciación genética son inciertos. Las poblaciones de la Sierra de Los Tuxtlas, Veracruz, sin embargo, están diferenciadas marcadamente en ambas especies.

\section{INTRODUCTION}

The biochemical study of the genetics of bird populations is entering its third decade, and many species have been studied in detail (Barrowclough and Johnson 1988). However, the coverage of the full diversity of birds has been uneven: most studies have treated north temperate species, and relatively few studies have dealt with tropical or insular species. The only published study of variation and differentiation in montane tropical bird species concerns the honeycreepers

\footnotetext{
' Received 19 July 1991. Accepted 8 November 1991.
}

of the Hawaiian Islands (Johnson et al. 1989); no information has been published on the genetics of bird species in the patchy, montane forest habitats of the tropics of either the New or Old World.

In this paper, we analyze patterns of genetic variation within and among four populations each of two species, the Chestnut-capped Brush-finch (Atlapetes brunneinucha) and the Common Bushtanager (Chlorospingus ophthalmicus), based on genetic variation detected by allozyme electrophoresis. The degree of genetic differentiation among populations is evaluated, providing data on two montane tropical species, a set of bird 


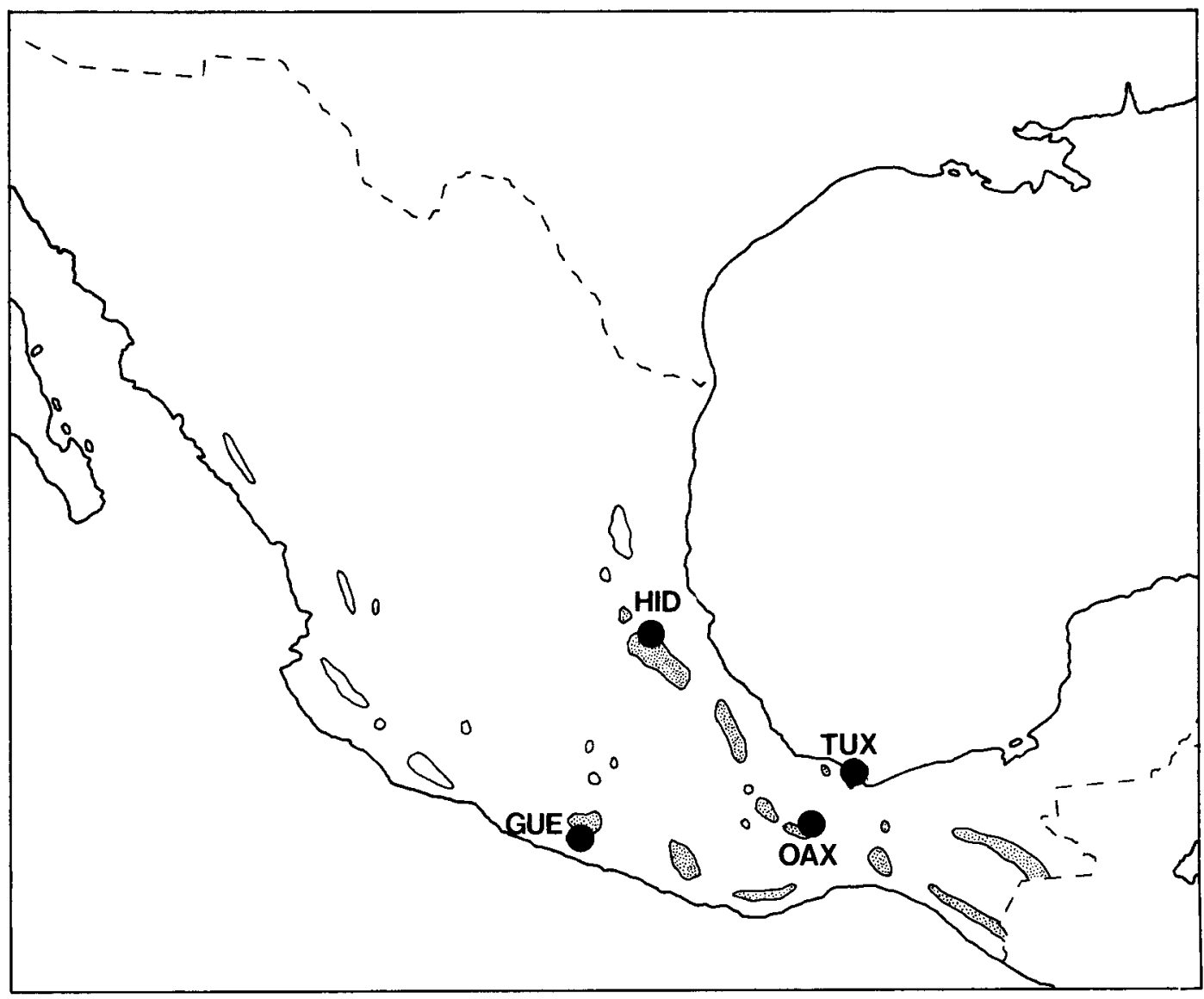

FIGURE 1. Distribution of cloud forest and the two species under study in Mexico, showing sample localities (abbreviations follow Table 1). Patches of cloud forest in which the study species are known to occur are stippled.

species not previously studied genetically. Both species are ecologically restricted to isolated, midelevation patches of cloud forest and humid pineoak forest (Fig. 1; Rzedowski 1978) in southern Mexico (Navarro 1986), and are distributed in such habitats south to southern South America (American Ornithologists' Union 1983). These habitat islands have probably undergone cycles of expansion and connection, and contraction and isolation during the past several tens of thousands of years. Both species are highly polytypic across their ranges (and within the area treated in this study), varying in aspects of plumage coloration, size, and shape. The four habitat islands included in this study differ markedly in size (from about $10 \mathrm{~km}^{2}$ to more than $100 \mathrm{~km}^{2}$ ) and degree of isolation (from about $40 \mathrm{~km}$ to more than $300 \mathrm{~km}$ of intervening lowland hab- itat). Comparisons among these populations should elucidate factors influencing the differentiation of these populations.

\section{METHODS}

Tissue from 97 individuals ( 39 brush-finches and 58 bush-tanagers) from four sites in cloud forest in Mexico was analyzed using allozyme electrophoresis. The sites are as follows: Hidalgo, Sierra de la Huasteca, Tlanchinol; Oaxaca, Nudo de Zempoaltépetl, Totontepec; Veracruz, Sierra de los Tuxtlas, El Bastonal; and Guerrero, Sierra de Atoyac, Puerto el Gallo (Fig. 1, Table 1). Individuals were captured in mist nets and prepared as partial study skins/skeletons. Samples of heart, muscle, and liver tissue were stored in liquid nitrogen. All specimens are deposited in the collections of the Museo de Zoología, Facultad de 
TABLE 1. Sample sizes, heterozygosities, and gene flow $(\mathrm{Nm})$ estimates for Mexican populations of Chestnutcapped Brush-finches and Common Bush-tanagers in Mexico. Standard errors are given in parentheses. Values of the gene flow parameter $\mathrm{Nm}$ listed for individual populations result from removal of that population, with percent change given in brackets. Abbreviations for populations are given in boldface.

\begin{tabular}{lrlll}
\hline \hline \multicolumn{1}{c}{ Locality } & $n$ & \multicolumn{1}{c}{$H_{\text {obs }}$} & \multicolumn{1}{c}{$N m^{\mathrm{a}}$} & $N m^{\mathrm{b}}$ \\
\hline Chestnut-capped Brush-finches & & & \\
$\quad$ Hidalgo & 9 & $0.069(0.025)$ & $0.272[+20.9 \%]$ & \\
Oaxaca & 14 & $0.059(0.063)$ & $0.161[-28.4 \%]$ \\
$\quad$ Los Tuxtlas & 3 & $0.046(0.027)$ & $0.388[+72.4 \%]$ & \\
$\quad$ Guerrero & 13 & $0.101(0.039)$ & $0.155[-31.1 \%]$ & \\
$\quad$ Overall & & & 0.225 & \\
Common Bush-tanagers & & & & \\
$\quad$ Hidalgo & 23 & $0.065(0.022)$ & $0.121[-60.1 \%]$ \\
$\quad$ Oaxaca & 14 & $0.054(0.021)$ & $0.233[-23.1 \%]$ & \\
Los Tuxtlas & 8 & $0.050(0.032)$ & $2.581[+751.8 \%]$ & \\
$\quad$ Guerrero & 13 & $0.029(0.012)$ & $0.235[-22.4 \%]$ & 0.551 \\
$\quad$ Overall & & & 0.303 & \\
\hline
\end{tabular}

${ }^{a}$ From average frequencies of private alleles (Slatkin 1985).

${ }^{b}$ From $F$-statistics (Slatkin and Barton 1989).

Ciencias, Universidad Nacional Autónoma de México, and the Field Museum of Natural History in Chicago.

Equal portions of heart, muscle, and liver were homogenized in a $1 \mathrm{mM}$ disodium EDTA/100 $\mathrm{mM}$ Tris base/0.2 mM NAD, NADP, and ATP buffer, centrifuged for $20 \mathrm{~min}$ at $12,000 \mathrm{rpm}$, and the supernatants drawn into capillary tubes for storage. Samples were electrophoresed for 4-6 hr on $11 \%$ starch gels, depending on the specific analysis desired. Gels were sliced horizontally, and each slice stained using specific protein assays from Shaw and Prasad (1970) and Harris and Hopkinson (1978). Each sample was scored at 29 presumptive genetic loci, including the following (Enzyme Commission codes from Harris and Hopkinson 1978): aconitase (ACON; enzyme number 4.2.1.3), acid phosphatase (ACP, erythrocytic acid phosphatase form; 3.1.3.2), adenosine deaminase (ADA; 3.5.4.4), adenylate kinase (AK; 2.7.4.3; 2 loci), creatine kinase (CK; 2.7.3.2; 3 loci), esterase (ES; 3.1.1.1), fumarate hydratase $(\mathrm{FH} ; 4.2 .1 .2)$, guanine deaminase (GDA; 3.5.4.3), glutamate dehydrogenase (GLUD; 1.4.1.3), aspartate aminotransferase (GOT; 2.6.1.1), glycerol-3-phosphate dehydrogenase (GPD; 1.1.1.8), glucose-phosphate isomerase (GPI; 5.3.1.9), alanine aminotransferase (GPT; 2.6.1.2), isocitrate dehydrogenase (IDH; 1.1.1.42), lactate dehydrogenase (LDH; 1.1.1.27; 2 loci), malate dehydrogenase (MDH; 1.1.1.37; 2 loci), mannose-phosphate isomerase (MPI;
5.3.1.8), peptidases (PEP; 3.4.11; 3 loci, 2 using Leu-Ala, 1 using Leucylaminopeptide), 6-phosphogluconate dehydrogenase (PGD; 1.1.1.44), phosphoglucomutase (PGM; 2.7.5.1; 2 loci), and sorbitol dehydrogenase (SDH; 1.1.1.14). To assure correct assignment of homologies between gels, reference individuals were included on each gel.

Allele frequencies and mean observed heterozygosities $H_{o b s}$ were calculated, and departure from Hardy-Weinberg equilibrium was tested by a chi-square test with Levene's correction for small sample sizes, using BIOSYS-1, version 1.7 (Swofford and Selander 1989). Differences among populations in heterozygosity were tested by nonparametric comparisons of distributions of individual heterozygosities averaged across loci. The genetic distance measures of Nei (1978) and Rogers (as modified by Wright 1978) were calculated. Fixation indices ( $F$-statistics, from BIOSYS-1) were used to summarize the distribution of genetic variation within and among populations. The private alleles method of Slatkin (1985) was used to estimate rates of gene flow $(\mathrm{Nm})$ among populations, with the contribution of individual populations to the overall calculation evaluated by sequentially omitting each population and recalculating, each population's importance being measured by the change caused by its omission (Slatkin 1985); $\mathrm{Nm}$ was also calculated from $F$-statistics (after Slatkin and Barton 1989). An index of level of differentiation of 
each population was calculated as the mean modified Rogers' genetic distance to the remaining three populations. Based on inspection of maps and on-site exploration, the four habitat islands were ranked as to size (smallest to largest: Los Tuxtlas, Guerrero, Hidalgo, Oaxaca). Geographic distances among populations were calculated as great-circle distances among the latitude-longitude points (Maling 1989). A ranking by mean geographic distance to all other islands was used to evaluate geographic isolation (least to most isolated: Oaxaca, Hidalgo, Los Tuxtlas, Guerrero). Mantel's tests comparing genetic distance matrices or genetic and geographic distance matrices were performed using NTSYS-pc, version 1.40 (Rohlf 1988).

Two algorithms were used to estimate branching relationships among populations. We calculated phenetic trees using the unweighted pairgroup method of analysis (UPGMA; Swofford and Olsen 1990). A minimum-evolution technique was applied to the data using the program FREQPARS (Swofford and Berlocher 1987). Because of problems of nondetection of alleles and coding allozyme data (Swofford and Olsen 1990), cladistic analyses were not conducted.

\section{RESULTS}

Within-population variation. Levels of variation within populations of the two species are comparable (Table 1), with heterozygosities averaging 0.069 and 0.050 in Chestnut-capped Brushfinches and Common Bush-tanagers, respectively. The two species do not differ significantly in heterozygosity ( $t$-test, $P>0.20$ ). Heterozygosities are not significantly correlated between the species across islands. Populations of Chestnutcapped Brush-finches show significant heterogeneity in levels of heterozygosity (Kruskal-Wallis test, $\mathrm{df}=3, H=9.838, P<0.025$ ); heterogeneity of levels of heterozygosity in Common Bush-tanagers is marginally significant (KruskalWallis test, $\mathrm{df}=3, H=6.413 ; 0.10<P<0.05$ ). In both species, genetic variability is positively related (Spearman rank correlation coefficients) to island size. This pattern is produced by the tendency of at least one of the populations of the smallest habitat islands (Guerrero or Los Tuxtlas) to show very low levels of variation. The relationship between genetic variability and island isolation is less clear: genetic variability is negatively related to isolation in Common Bush- tanagers but not in Chestnut-capped Brushfinches (Spearman rank correlation coefficients). Because the number of islands sampled is small, statistical testing is not possible; still, associations between habitat island size and genetic variability and possibly between habitat island isolation and genetic variability in the two species are suggestive.

Among-population variation. Differentiation among populations in both of the species is marked, with fixed differences and large frequency differences among populations at several loci (Appendix 1). For example, in Chestnutcapped Brush-finches, the PGM2-b allele is fixed in the Hidalgo population, but the PGM2-a allele is fixed in the Los Tuxtlas population; both alleles are present in the other two populations. In Common Bush-tanagers, the ACON-c allele is fixed in the Los Tuxtlas population but is found nowhere else in the species' range. Strong frequency differences are found at several other loci. Genetic distances also reflect high levels of among-population differentiation, especially for the Los Tuxtlas populations of both species (Fig. 2).

Wright's $F$-statistics also indicate considerable genetic differentiation among populations. In Chestnut-capped Brush-finches, fixation indices are $F_{i s}=0.003, F_{i t}=0.282$, and $F_{s t}=0.280$, and in Common Bush-tanagers, fixation indices are $F_{i s}=-0.032, F_{i t}=0.290$, and $F_{s t}=0.312 . F_{s t} \mathrm{~s}$ in the two species are highly significantly different from zero (bootstrapping across loci, 200 replications, Mann-Whitney $U$-test, both $P<$ 0.0001 ), and not significantly different from one another (bootstrapping across loci, 200 replications, Mann-Whitney $U$-test, $P>0.19$ ).

Slatkin's (1985) method of estimating levels of gene flow indicates that few individuals are exchanged among populations in either species. Overall estimates of the number of migrants per generation are 0.225 and $0.303(0.643$ and 0.551 in calculations from $F$-statistics) in Chestnutcapped Brush-finches and Common Bush-tanagers, respectively. The jackknife manipulation suggested by Slatkin (1985) indicates that one or two populations are especially isolated from the rest of each of the species' ranges (Table 1). Removal of the Los Tuxtlas populations increases gene flow estimates by $72.4 \%$ and $751.8 \%$ for Chestnut-capped Brush-finches and Common Bush-tanagers, respectively. With the exception 


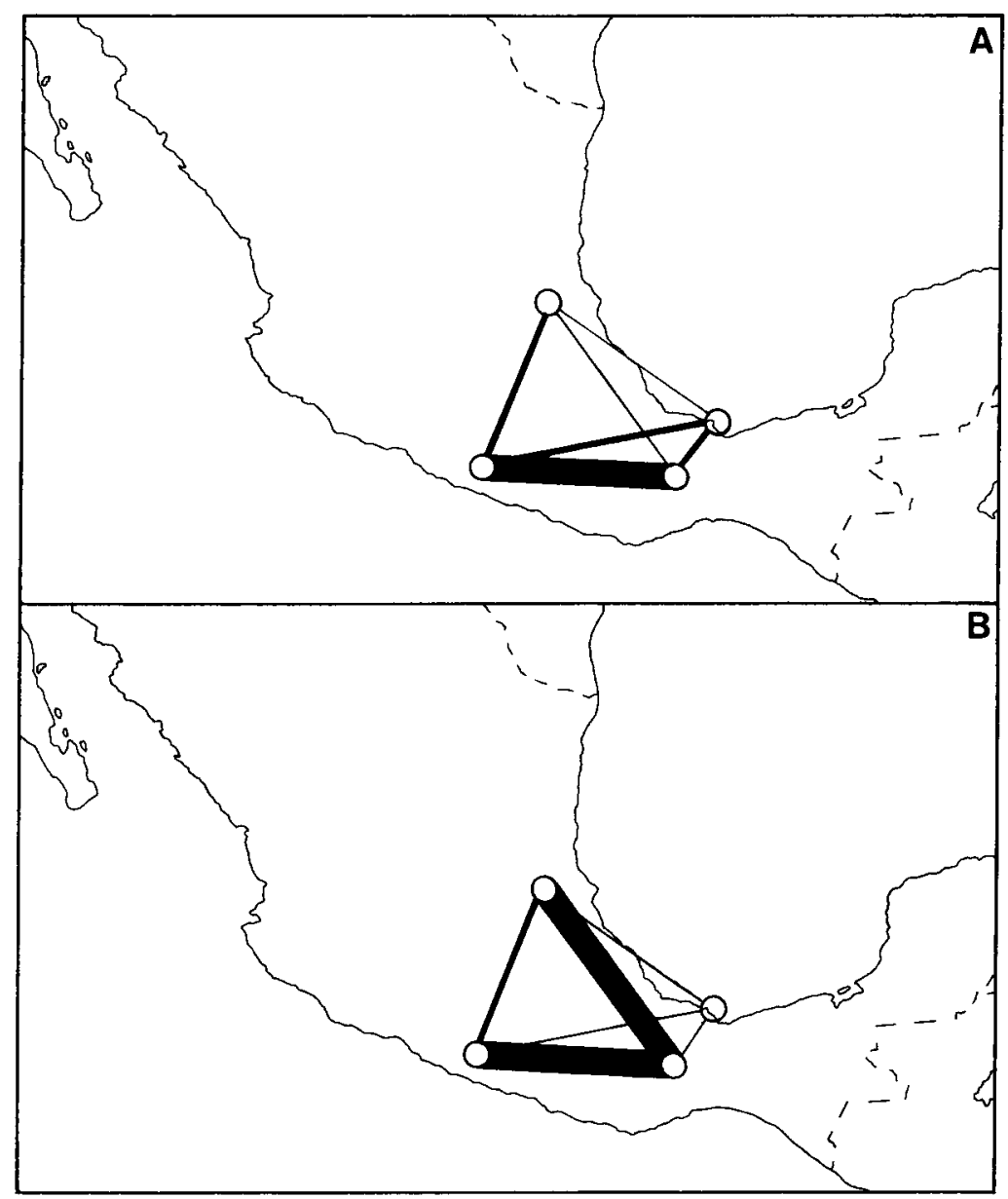

FIGURE 2. Geographic patterns of modified Rogers' genetic distances among populations of (A) Chestnutcapped Brush-finches and (B) Common Bush-tanagers. Thick lines indicate little differentiation $(0.05<D<$ $0.10)$; medium lines indicate moderate differentiation $(0.10<D<0.19)$; and thin lines indicate strong differentiation $(0.20<D<0.28)$.

of Chestnut-capped Brush-finches from Guerrero (removal of which causes a $20.9 \%$ increase in the calculations), removal of other populations of either species causes decreases in the gene flow estimates, suggesting that these populations are more interconnected genetically or historically (Slatkin 1985; Table 1). Hence, overall levels of gene flow in both species are limited, owing in part to the extreme isolation of the Los Tuxtlas populations.

Given the observation of limited gene flow in the two species, it is of interest to test for effects of geographic distance on levels of genetic differentiation of populations (Wright 1978). Mantel's tests comparing matrices of modified Rog- ers' genetic distances with the geographic distance matrix (Table 2) indicate that neither species shows a detectable isolation by distance relationship (both $P>0.05$ ). Elements of Rogers' genetic distance matrices of the two species are positively correlated, but a Mantel's test failed to establish significance $(r=0.539, P=0.400)$. Either the number of localities in this study is insufficient to detect these relationships, or isolation by distance relationships and common genetic distance matrix structure are not present in the populations under study.

We tested the effects of size and isolation of habitat islands on level of genetic differentiation by comparing rankings of size and isolation (see 
TABLE 2. Genetic distance matrices calculated from allozyme data (Nei's genetic distance above diagonal, modified Rogers' genetic distance below diagonal) for the two species, and matrix of geographic distances (km) among localities. Differentiation indices (mean Rogers' distance to other populations) are also presented.

\begin{tabular}{lccccc}
\hline \hline \multicolumn{1}{c}{ Locality } & HID & OAX & TUX & GUE & Diff. index \\
\hline Chestnut-capped Brush-finch & & & & & \\
$\quad$ Hidalgo, Sierra de la Huasteca & - & .043 & .075 & .034 & 0.222 \\
Oaxaca, Nudo de Zempoaltépetl & .207 & - & .020 & .004 & 0.149 \\
$\quad \begin{array}{l}\text { Veracruz, Sierra de los Tuxtlas } \\
\text { Guerrero, Sierra de Atoyac }\end{array}$ & .275 & .162 & - & .023 & 0.202 \\
Common Bush-tanager & .185 & .079 & .170 & - & 0.145 \\
$\quad$ Hidalgo, Sierra de la Huasteca & - & & & & \\
Oaxaca, Nudo de Zempoaltépetl & .080 & .005 & .060 & .011 & 0.143 \\
$\quad$ Veracruz, Sierra de los Tuxtlas & .239 & .224 & .051 & .002 & 0.120 \\
$\quad$ Guerrero, Sierra de Atoyac & .111 & .057 & .212 & -045 & 0.225 \\
Geographic distance & & & & & 0.127 \\
$\quad$ Hidalgo, Sierra de la Huasteca & - & & & & \\
Oaxaca, Nudo de Zempoaltépetl & 591 & - & & & \\
$\quad$ Veracruz, Sierra de los Tuxtlas & 488 & 181 & - & & \\
Guerrero, Sierra de Atoyac & 424 & 449 & 565 & & \\
\hline
\end{tabular}

Methods) with the index of genetic differentiation (Table 2). A negative relationship between island size and differentiation is marginally significant in Common Bush-tanagers (Spearman's rank correlation coefficient, $r=-0.80,0.10>$ $P>0.05$ ), but no relationship is evident in Chestnut-capped Brush-finches $(r=0.00, P>$ $0.50)$. Relationships between island isolation and differentiation are less clear, with correlations of -0.4 and 0.4 (both $P>0.50$ ) in Chestnut-capped Brush-finches and Common Bush-tanagers, respectively. Hence, relationships between levels of genetic differentiation and island characteristics are unresolved, although an effect of island size may be manifested in Common Bush-tanagers.

Estimates of branching relationships among populations are heavily algorithm-dependent, as each algorithm produces somewhat different results. UPGMA analyses indicate a sister relationship of the Oaxaca and Guerrero populations in both species, and then a branch to either the Hidalgo population or the Los Tuxtlas population (Fig. 3a). Trees based on the heuristic topology search algorithm of FREQPARS group Oaxaca and Hidalgo populations as sister taxa, then a branch to Los Tuxtlas, and finally a branch to Guerrero in both species (Fig. 3b).

\section{DISCUSSION}

Within-population genetic variation in Common Bush-tanagers and Chestnut-capped Brush- finches is more or less typical of other bird species studied to date (Evans 1987). Several lines of theoretical evidence predict that genetic variation should be reduced in small, isolated populations (Nei et al. 1975, Soulé 1976, Kimura 1983). However, in contrast to results from other taxonomic groups (e.g., Berry 1986), Boag (1988) found no tendency toward reduced variation in four studies of insular bird populations. In this study, we document reduced genetic variation in small insular populations of at least one of the two species. Since Boag's review, similar reductions have been documented in several insular populations of Aphelocoma jays (Peterson 1990), Common Chaffinches (Fringilla coelebs; Baker et al. 1990), and Hawaiian honeycreepers (Drepanidinae; Johnson et al. 1989). Hence, the studies available to Boag (1988) may have been too few to detect a real patten of reduced genetic variation in insular bird populations.

The extreme genetic differentiation in the two species in the present study is somewhat surprising in light of generally low levels of differentiation found in previous studies of other bird species (Barrowclough and Johnson 1988). However, inspection of species treated in previous studies reveals that almost all are either migratory, seasonally wandering, or introduced, which are life history characteristics that elevate levels of gene flow among populations or reduce the amount of differentiation expected. Many bird species, however, are highly sedentary; further- 

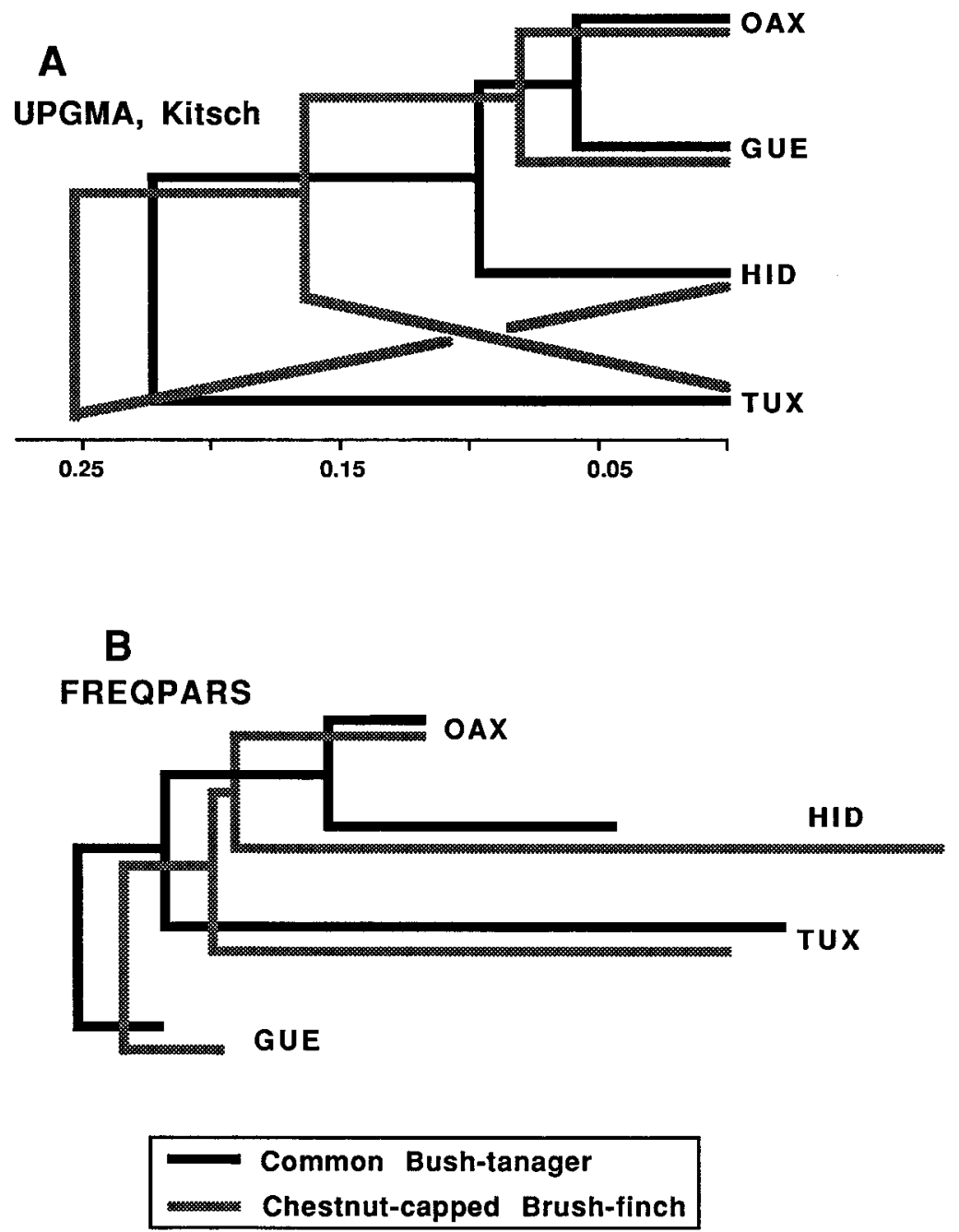

FIGURE 3. Dendrograms for four populations of Common Bush-tanagers and Chestnut-capped Brushfinches, as estimated by (A) UPGMA and (B) FREQPARS. Lengths for the FREQPARS trees in (B) are 8.03 and 10.29 for Common Bush-tanagers and Chestnut-capped Brush-finches, respectively. Site abbreviations follow Figure 1.

more, many tropical species' distributions have existed as such for much longer time periods than those of the largely temperate species yet studied. Recent studies of other sedentary bird populations support these ideas (e.g., Capparella 1988; Baker et al. 1990; Peterson 1990; Escalante, in prep.).

Populations of Chestnut-capped Brush-finches and Common Bush-tanagers in Mexico are strongly genetically differentiated, including fixed allelic differences among populations. Given that the study area covers only a small portion of the northern extreme of the species' distributions, and given that their populations are restricted to isolated habitat islands throughout, considerable genetic heterogeneity most likely exists across the species' entire distributions. Similar patterns of extreme genetic subdivision have been documented in another cloud forest-restricted species, the Unicolored Jay (Aphelocoma unicolor; Peterson 1990), and even in species resident in lowland forests with populations subdivided by rivers (Capparella 1988). Hence, sedentary bird species with discontinuous distributions may be 
highly genetically heterogeneous, opening many new avenues for study to investigators using biochemical techniques.

Estimates of rates of gene flow are important to understanding factors causing differentiation of populations (Slatkin 1985). Regardless of the method used in calculation, overall levels of gene flow in both species meet the criterion of $\mathrm{Nm} \leq$ 1 necessary for differentiation by genetic drift alone in neutral characters (Wright 1931). Although in Common Bush-tanagers the reduction in overall gene flow results chiefly from the extreme isolation of the Los Tuxtlas population, reduced gene flow is pervasive in Chestnutcapped Brush-finch populations studied. The general situation in both species, however, is one of sufficient genetic isolation that most of the populations should be able to differentiate by genetic drift alone.

Phylogenetic networks estimated are more or less concordant between the two species, but splitting patterns depend heavily on the algorithm employed. Branching patterns estimated by FREQPARS are identical between the species, which is fairly improbable $(P=0.067)$ if all distinguishable cladograms are equiprobable (Simberloff 1987). Results from UPGMA differ by one node between the two species, a degree of concordance more likely to be found by chance. The apparent concordance of the networks suggests common historical causation of patterns of differentiation in the two species.

Geographic patterning of genetic differentiation in the two species (Figs. 2 and 3 ) suggests that the Los Tuxtlas populations of both species, and, to a lesser degree, the Hidalgo population of Chestnut-capped Brush-finches and the Guerrero population of Common Bush-tanagers, are very differentiated from other populations of the species. Two alterative hypotheses for why these populations are so distinct can be considered: (1) they have been effectively isolated for a long period of time, or (2) they have been evolving at a faster rate than populations elsewhere in the species' ranges. More precisely, a testable hypothesis emerging from this study is that the extreme genetic differentiation observed can be explained by historical patterns of isolation of populations. To resolve this question, phylogenetic estimates based on an independent data set are needed; such a study is currently in progress (Peterson et al., in prep.).

\section{ACKNOWLEDGMENTS}

We would like to thank our many field companions for making these studies possible, especially Hesiquio Benítez Díaz, Noé Vargas Barajas, Scott Baker, and Fernando Villaseñor. Thanks also to Pamela Austin and John Hall for expert help in the laboratory. Thanks to John Bates, Shannon Hackett, and two anonymous reviewers for helpful comments on the manuscript. We thank the Dirección de Flora y Fauna Silvestres, Secretaria de Desarollo Urbano y Ecologia, of the Mexican government for providing permits for scientific collecting. Financial support was provided by the $\mathrm{Na}$ tional Science Foundation Dissertation Improvement Grant Program (BSR-8700850), National Geographic Society, Field Museum of Natural History, Chapman Fund (American Museum of Natural History), Sigma $\mathrm{Xi}$, the University of Chicago, the Facultad de Ciencias of UNAM, and the Dirección General de Asuntos del Personal Académico of UNAM (IN-201789).

\section{LITERATURE CITED}

American OrNithologists' Union. 1983. Checklist of North American birds. 6th ed. American Ornithologists' Union, Lawrence, KS.

BAKER, A. J., M. D. DenNison, A. LYNCH, AND G. LE GrAND. 1990. Genetic divergence in peripherally isolated populations of chaffinches in the Atlantic islands. Evolution 44:981-999.

Barrowclough, G. F., AND N. K. Johnson. 1988. Genetic structure of North American birds, $p$. 1630-1638. In H. Ouellet [ed.], Acta XIX Congr. Int. Ornithol. Nat. Mus. Nat. Sci., Ottawa, Canada.

BERRY, R. J. 1986. Genetics of insular populations of mammals, with particular reference to differentiation and founder effects in British small mammals. Biol. J. Linn. Soc. 28:205-230.

BOAG, P. T. 1988. The genetics of island birds, $p$. 1550-1563. In H. Ouellet [ed.], Acta XIX Congr. Int. Ornithol. Nat. Mus. Nat. Sci., Ottawa, Canada.

Capparella, A. P. 1988. Genetic variation in Neotropical birds: implications for the speciation process, p. 1658-1664. In H. Ouellet [ed.], Acta XIX Congr. Int. Ornithol. Nat. Mus. Nat. Sci., Ottawa, Canada.

Evans, P. G. H. 1987. Electrophoretic variability of gene products, p. 105-162. In F. Cooke and P. A. Buckley [eds.], Avian genetics. Academic Press, London.

HARRIs, H., AND D. A. HoPKINSON. 1978. Handbook of enzyme electrophoresis in human genetics. North-Holland Publishing, Amsterdam.

Johnson, N. K., J. A. Marten, AND C. J. RalPh. 1989. Genetic evidence for the origin and relationships of Hawaiian honeycreepers (Aves: Fringillidae). Condor 91:379-396.

KIMURA, M. 1983. The neutral theory of molecular evolution. Cambridge Univ. Press, Cambridge, England.

Maling, D. H. 1989. Measurements from maps: 
principles and methods of cartometry. Pergamon Press, Oxford, England.

Navarro S., A. G. 1986. Distribución altitudinal de las aves en la Sierra de Atoyac, Guerrero. Prof. thesis, Univ. Nac. Autón. México, México.

NEI, M. 1978. Estimation of average heterozygosity and genetic distance from a small number of individuals. Genetics 89:583-590.

Nei, M., T. Maruyama, and R. Chakraborty. 1975. The bottleneck effect and genetic variability in populations. Evolution 29:1-10.

Peterson, A. T. 1990. Evolutionary relationships of the Aphelocoma jays. Ph.D.diss., Univ. Chicago, Chicago.

RoHLF, F. J. 1988. NTSYS-pc: numerical taxonomy and multivariate analysis system, version 1.40. Exeter Publishing, Setauket, NY.

RzEDOwski, J. 1978. Vegetación de México. Editorial Limusa, México.

Shaw, C. R., AND R. Prasad. 1970. Starch-gel electrophoresis of enzymes: a compilation of recipes. Biochem. Genet. 4:297-320.

SimberlofF, D. 1987. Calculating the probabilities that cladograms match: a method of biogeographic inference. Syst. Zool. 36:175-195.

SLATKIN, M. 1985. Rare alleles as indicators of gene flow. Evolution 39:53-65.
Slatkin, M., And N. H. Barton. 1989. A comparison of three indirect methods for estimating average levels of gene flow. Evolution 43:1349-1368.

Soulé, M. E. 1976. Allozyme variation: its determinants in space and time, p. 60-77. In F. J. Ayala [ed.], Molecular evolution. Sinauer Assoc., Inc., Sunderland, MA.

SwoFFord, D. L., AND S. H. BERLOCHER. 1987. Inferring evolutionary trees from gene frequency data under the principle of maximum parsimony. Syst. Zool. 36:293-325.

SwoFFord, D. L., AND G. J. Olsen. 1990. Phylogeny reconstruction, p. 411-501. In D. M. Hillis and C. Moritz [eds.], Molecular systematics. Sinauer Assoc., Inc., Sunderland, MA.

Swofford, D. L., AND R. B. Selander. 1989. BIOSYS-1: a computer program for the analysis of allelic variation in population genetics and biochemical systematics. Illinois Nat. Hist. Surv., Champaign, IL.

WrIGHT, S. 1931. Evolution in Mendelian populations. Genetics 16:97-159.

WRIGHT, S. 1978. Evolution and the genetics of populations. Vol. 4. Variability within and among natural populations. Univ. Chicago Press, Chicago. 
APPENDIX. Allele frequencies of four populations each of Chestnut-capped Brush-finches and Common Bushtanagers in Mexico. Allele designations are not equivalent in the two species. Loci invariant in both species include ACP, AK1, AK2, CK1, CK2, CK3, GLUD, GPT, LDH2, MDH2, PEP (leucylaminopeptide), and SORDH.

\begin{tabular}{|c|c|c|c|c|c|c|c|c|c|}
\hline \multirow[b]{2}{*}{ Locus } & \multirow[b]{2}{*}{ Allele } & \multicolumn{4}{|c|}{ Brush-finches } & \multicolumn{4}{|c|}{ Bush-tanagers } \\
\hline & & HID & $\overline{\mathrm{OAX}}$ & TUX & GUE & HID & OAX & TUX & GUE \\
\hline \multirow[t]{3}{*}{ ACON } & a & 1.000 & 1.000 & 1.000 & 1.000 & 1.000 & 0.964 & - & 0.885 \\
\hline & b & - & - & - & - & - & 0.036 & - & 0.115 \\
\hline & c & - & - & - & - & - & - & 1.000 & - \\
\hline \multirow[t]{5}{*}{ ADA } & a & - & 0.286 & 0.667 & 0.192 & 0.020 & 0.036 & 0.071 & 0.077 \\
\hline & b & 0.100 & - & - & 0.039 & 0.020 & - & 0.071 & - \\
\hline & c & - & - & - & 0.039 & 0.900 & 0.964 & 0.572 & 0.923 \\
\hline & $\mathrm{d}$ & 0.850 & 0.714 & 0.333 & 0.730 & - & - & 0.215 & - \\
\hline & $\mathrm{e}$ & 0.050 & - & - & - & 0.060 & - & 0.071 & - \\
\hline \multirow[t]{4}{*}{ ES } & a & - & 0.036 & - & - & 1.000 & 1.000 & 1.000 & 1.000 \\
\hline & b & - & - & - & 0.039 & - & - & - & - \\
\hline & $\mathrm{c}$ & 0.950 & 0.964 & 1.000 & 0.961 & - & - & - & - \\
\hline & $\mathrm{d}$ & 0.050 & - & - & - & - & - & - & - \\
\hline \multirow[t]{2}{*}{ FUM } & $\mathbf{a}$ & 0.250 & 0.562 & 0.167 & 0.115 & 0.980 & 1.000 & 1.000 & 1.000 \\
\hline & b & 0.750 & 0.438 & 0.833 & 0.885 & 0.020 & - & - & - \\
\hline \multirow[t]{4}{*}{ GDA } & $\mathbf{a}$ & - & - & - & 0.192 & 0.960 & 1.000 & 1.000 & 0.900 \\
\hline & b & 1.000 & 0.964 & 1.000 & 0.731 & 0.040 & - & - & 0.050 \\
\hline & c & - & 0.036 & - & - & - & - & - & 0.050 \\
\hline & d & - & - & - & 0.077 & - & - & - & - \\
\hline \multirow[t]{2}{*}{ GOT } & a & 1.000 & 1.000 & 1.000 & 1.000 & 0.587 & 0.821 & 1.000 & 1.000 \\
\hline & b & - & - & - & - & 0.413 & 0.179 & - & - \\
\hline \multirow[t]{2}{*}{ GPD } & a & 0.350 & 1.000 & 1.000 & 1.000 & 1.000 & 1.000 & 1.000 & 1.000 \\
\hline & b & 0.650 & - & - & - & - & - & - & - \\
\hline \multirow[t]{3}{*}{ GPI } & a & 0.850 & 0.071 & 0.333 & 0.308 & - & - & - & 0.039 \\
\hline & b & 0.150 & 0.929 & 0.667 & 0.654 & 1.000 & 1.000 & 1.000 & 0.962 \\
\hline & c & - & - & - & 0.038 & - & - & - & - \\
\hline \multirow[t]{4}{*}{ IDH } & $\mathrm{a}$ & 1.000 & 1.000 & 1.000 & 1.000 & 0.020 & - & - & - \\
\hline & b & - & - & - & - & 0.060 & - & - & - \\
\hline & c & - & - & - & - & 0.920 & 0.964 & 1.000 & 0.885 \\
\hline & d & - & - & - & - & - & 0.036 & - & 0.115 \\
\hline \multirow[t]{2}{*}{ LDH1 } & a & 0.950 & 1.000 & 1.000 & 1.000 & 1.000 & 1.000 & 1.000 & 1.000 \\
\hline & $\mathrm{b}$ & 0.050 & - & - & - & - & - & - & - \\
\hline \multirow[t]{2}{*}{ MDH 1} & a & 1.000 & 1.000 & 0.833 & 1.000 & 1.000 & 1.000 & 1.000 & 1.000 \\
\hline & b & - & - & 0.167 & - & - & - & - & - \\
\hline \multirow[t]{4}{*}{ MPI } & $\mathrm{a}$ & - & - & 0.333 & - & 0.280 & 0.036 & - & - \\
\hline & b & 0.950 & 0.964 & 0.667 & 1.000 & - & 0.036 & - & - \\
\hline & c & 0.050 & 0.036 & - & - & 0.700 & 0.892 & 1.000 & 1.000 \\
\hline & d & - & - & - & - & 0.020 & 0.036 & - & - \\
\hline PEP1 & a & 0.950 & 1.000 & 1.000 & 1.000 & - & 0.108 & - & 0.039 \\
\hline & b & 0.050 & - & - & - & 0.923 & 0.821 & 1.000 & 0.961 \\
\hline & c & - & - & - & - & 0.077 & 0.071 & - & - \\
\hline PEP2 & a & 1.000 & 1.000 & 1.000 & 1.000 & 0.100 & - & - & - \\
\hline & b & - & - & - & - & - & - & 0.063 & - \\
\hline & c & - & - & - & - & 0.900 & 1.000 & 0.937 & 1.000 \\
\hline PGD & $\mathrm{a}$ & 0.050 & - & - & - & 0.020 & - & - & - \\
\hline & b & 0.050 & - & - & - & 0.040 & - & 0.500 & - \\
\hline & c & 0.900 & 0.929 & 1.000 & 0.846 & 0.940 & 1.000 & 0.500 & 1.000 \\
\hline & d & - & 0.071 & - & 0.154 & - & - & - & - \\
\hline PGM1 & $\mathbf{a}$ & 0.950 & 1.000 & 1.000 & 1.000 & 0.960 & 0.964 & 1.000 & 1.000 \\
\hline & b & 0.050 & - & - & - & 0.040 & - & - & - \\
\hline & c & - & - & - & - & - & 0.036 & - & - \\
\hline PGM2 & a & - & 0.357 & 1.000 & 0.346 & 0.100 & 0.107 & - & - \\
\hline & b & 1.000 & 0.607 & - & 0.615 & 0.900 & 0.821 & 1.000 & 0.961 \\
\hline & c & - & 0.036 & - & 0.039 & - & 0.072 & - & - \\
\hline & $\mathrm{d}$ & - & - & - & - & - & - & - & 0.039 \\
\hline
\end{tabular}

